MEDICINE AND THE LAW

\title{
Is it ever justified for doctors to sue their patients whose allegations against them have been dismissed by the courts or the Health Professions Council of South Africa?
}

\author{
D J McQuoid-Mason \\ David McQuoid-Mason is Professor of Law at the Centre for Socio-Legal Studies, University of KwaZulu-Natal, Durban, South Africa, and publishes \\ and teaches in medical law.
}

Corresponding author: D J McQuoid-Mason (mcquoidm@ukzn.ac.za)

Doctors should be cautious about suing their patients, because it may generate bad publicity. Where a criminal or civil case or complaint to the Health Professions Council of South Africa by a patient about a doctor's professional conduct is withdrawn or dismissed, a doctor may only sue the patient for defamation if it can be proved that the patient acted from malice, spite or an improper motive. Doctors may only sue patients for malicious prosecution or abuse of civil proceedings if such patients acted with 'malice' and 'without reasonable and probable cause'. If a doctor successfully defends a case against a patient, the court will usually order the patient to pay the doctor's costs.

S Afr Med J 2015;105(12):1010-1011. DOI:10.7196/SAMJ.2015.v105i12.10238

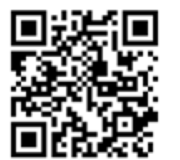

The Minister of Health has made public statements condemning the threat to health services by 'pocketlining' lawyers who 'care less about the concept of patient safety', and work 'in syndicates' to encourage litigation against healthcare professionals and hospital services. ${ }^{[1]}$ The Law Society of South Africa responded that legal practitioners 'cannot "manufacture" malpractice injuries' because the evidence is 'substantiated by experts', and if there is collusion between lawyers and doctors there are mechanisms in the relevant professional bodies and law enforcement agencies that can deal with it. ${ }^{[2]}$

The controversy about patients suing doctors raises the question of whether, in certain situations, the converse applies and doctors can sue their patients. We must therefore consider whether it is ever justified for doctors to sue their patients (or for their lawyers to advise them to do so), where they have successfully defended allegations made against them in criminal or civil cases, or in disciplinary hearings by the Health Professions Council of South Africa (HPCSA). The answer depends upon the nature of the allegations against the doctors, the manner in which they were made, and to whom the complaints were made. This can be clarified by considering situations where the allegations have been dismissed by (i) a criminal court; (ii) a civil court; and (iii) a disciplinary inquiry of the HPCSA.

However, doctors are advised to be cautious about suing their patients because this may generate more bad publicity than occurred when the patient originally complained about or sued the doctor. This has been the experience in the USA when doctors have sued patients for defamation arising from comments made on the social media, even in the rare cases where they have succeeded. ${ }^{[3]}$

\section{Dismissal of a criminal charge}

May doctors who have been acquitted of a crime or have had a criminal charge against them withdrawn sue the patient who complained about them for defamation or malicious prosecution?

\section{Defamation}

Defamation occurs where a person's reputation is lowered in the eyes of others, ${ }^{[4]}$ e.g. it is defamatory to state that a person has committed a crime. ${ }^{[5]}$ However, the law encourages people to report alleged crimes to the police by protecting them from being sued for defamation - even if their report to the police is based on a mistaken but honest belief. This is because a person who suspects that a crime has been committed may have a moral or social or legal duty to report it to the police, who have a reciprocal interest in receiving reports of criminal conduct.

People reporting alleged crimes are covered by a 'qualified privilege' unless the subjects of their reports can prove that such people acted 'maliciously. ${ }^{[6]}$ 'Malice' means that the person making the report did not have an honest belief when making it, but acted out of spite or an improper motive. ${ }^{[4]} \mathrm{A}$ doctor whose criminal case has been dismissed by the court, or if the prosecutors have withdrawn the charge or refused to prosecute, may therefore not sue a patient for defamation unless the doctor can prove that the patient's report to the police was based on malice. ${ }^{[6]}$

The same 'privilege' extends to statements made by complainants or witnesses during a criminal trial. Where such allegations are made in court documents or during a trial, they are subject to a qualified privilege and those making them may not be sued for defamation. ${ }^{[7]}$ Such allegations may only result in a claim for defamation if it is shown that the person making them acted out of malice, or intentionally introduced irrelevant defamatory statements, not supported by reasonable grounds, into the proceedings. ${ }^{[7]}$

\section{Malicious prosecution}

Malicious prosecution occurs where people intentionally abuse the criminal justice system by reporting a crime to the police because of 'malice' and do not have 'reasonable and probable cause' for their allegations. ${ }^{[8]}$ As in defamation cases, 'malice' in malicious prosecution cases means that the person making the report to the police was not acting in good faith, but out of spite or an improper motive. ${ }^{[9]}$ Absence of 'reasonable and probable cause' in malicious prosecution 
cases means that the person making the report had no reasonable grounds for suspecting that a crime had been committed by the person concerned ${ }^{[9]} \mathrm{A}$ complainant who was not acting with 'malice' and who has 'reasonable and probable cause' for making a report to the police cannot be sued by the person who is the subject of their report.

Doctors cannot claim damages for malicious prosecution from patients who lay criminal complaints against them with the police if they are subsequently found not guilty by the courts - unless they can prove that the patients acted 'maliciously' and 'without reasonable and probable cause. ${ }^{\text {'[] }}$ The same applies to criminal complaints where prosecutors have withdrawn charges or declined to prosecute. ${ }^{[8]}$ In cases where doctors are found not guilty of alleged crimes, the courts may still refer these to the HPCSA if they believe that such doctors acted unprofessionally, or the expert witnesses supporting them behaved unprofessionally. ${ }^{[10]}$

\section{Dismissal of a civil case}

As in the case of dismissal of criminal proceedings, where a patient unsuccessfully sues a doctor in a civil case for damages arising from medical malpractice or other unprofessional conduct (such as failure to obtain an informed consent or breach of confidentiality), the doctor may only sue the patient for defamation or abuse of civil proceedings in very limited circumstances.

\section{Defamation}

Stating that a professional person is incompetent or has acted unprofessionally is generally regarded as defamatory because it lowers their reputation in the eyes of society, their colleagues and their clients. ${ }^{[11]}$ However, as in criminal cases, allegations that are made in court documents or during a civil trial are subject to a 'qualified privilege' and those making them may not be sued for defamation $^{[7]}$ - unless it is shown that the person making them acted maliciously, or intentionally introduced irrelevant defamatory statements into the proceedings. ${ }^{[7]}$

When a civil claim by a patient alleging professional incompetence or unprofessional conduct by a doctor is dismissed by a court, the court will usually make the unsuccessful patient pay the doctor's costs of defending the action. The successful doctor will not have an action for defamation unless he or she can prove that the patient acted out of malice. ${ }^{[4]}$ However, as in criminal cases, in civil cases where a patient's claim has been dismissed the courts may still refer unprofessional conduct by the successful doctors or expert witnesses to the HPCSA. ${ }^{[10]}$

\section{Abuse of civil proceedings}

Where courts dismiss civil claims against defendants, such defendants may not sue the people bringing the action unless they can prove that they (and/or their lawyers) abused the use of the civil proceedings in the case. In cases of abuse of civil proceedings - as with malicious prosecution - people bringing the claims must prove that the unsuccessful litigants acted out of malice, spite or an improper motive, and without reasonable and probable cause. ${ }^{[7]}$

Doctors wishing to bring a civil case against an unsuccessful patient based on abuse of civil proceedings must prove that the patient acted 'maliciously' and 'without reasonable and probable cause. ${ }^{3}{ }^{[7]}$ In medical malpractice cases dismissed by the courts, the unsuccessful patients will usually be ordered to pay the legal costs of the successful defending doctors.

\section{Dismissal of a complaint to the HPCSA}

If an unfounded complaint is laid with a quasi-judicial body, such as a professional disciplinary body, against a professional person registered with such a body, the communication will be 'privileged' unless such person can show that the complainant acted with an improper motive such as ill-will, spite or malice. ${ }^{[4]}$

As the purpose of the HPCSA is to protect the public and guide the profession, a patient who believes that a doctor has acted unprofessionally is entitled to lay a complaint with the HPCSA and to be protected from any legal action for defamation. Therefore, if a patient complains to the HPCSA about the conduct of a doctor, the patient's complaint will be 'privileged' and immune from litigation by the doctor concerned - unless the doctor can show that the complaint was unjustified and the patient had acted out of malice, spite or an improper motive. Communications between patients and the HPCSA are privileged because patients are entitled to complain to the HPCSA about what they regard as unprofessional conduct and the HPCSA has a reciprocal interest in receiving such information. ${ }^{[4]}$

On receipt of a complaint against a doctor, the registrar of the HPCSA must give the doctor an opportunity to provide an explanation to a preliminary committee of inquiry ${ }^{[12]}$ If the preliminary committee is satisfied with the doctor's explanation, no further action will be taken, and the registrar will advise the patient accordingly. ${ }^{[12]}$ In such circumstances doctors may not sue patients unless they can show that the patient acted by malice or an improper motive.

However, if the preliminary committee is not satisfied with the doctor's explanation, it may ask the doctor to appear before it to give evidence or decide to refer the case to a professional conduct inquiry. ${ }^{[12]}$ If a preliminary inquiry or professional conduct hearing decides that the doctor is not guilty of unprofessional conduct, the doctor may not sue the patient who complained, unless it can be proven that the patient acted from malice or an improper motive.

\section{Conclusion}

Doctors are reminded to be cautious when considering whether or not to sue their patients, because it may generate more publicity than the original complaint against them did. Doctors against whom a criminal or civil case or complaint to the HPCSA has been withdrawn or dismissed may not sue a patient who instituted such a case or complaint for defamation, unless it can be proven that the patient's conduct was based on malice. Doctors who wish to sue patients for malicious prosecution or abuse of civil proceedings must show that such patients acted intentionally with 'malice' and 'without reasonable and probable cause'. The courts will usually award costs to doctors who successfully defend cases against their patients.

1. Motsoaledi A. Doctors call for lawyers to get out of hospitals. S Afr J Bioethics Law 2015;8(1):4-6. 2. Editorial. LSSA concern at Health Minister's plans for dealing with medical negligence victims. De Rebus 2015;May(Issue 552):21.

3. Segal J. When doctors sue patients - defamation is devastating - but a lawsuit could make it worse. Medical Justice 2015. http://medicaljustice.com/when-doctors-sue-patients-defamation-isdevastating-but-a-lawsuit-could-make-it-worse/ (accessed 20 August 2015).

Neethling J. Potgieter JM, Visser PJ. Law of Delict. 4th ed. Durban: Butterworths, 2001:338-350.

4. Neethling J, Potgieter JM, Viss

5. Sutter v Brown $1926 \mathrm{AD} 155$.
6. Basner v Trigger $1946 \mathrm{AD} 83$.

7. Cf. Joubert v Venter 1985 (1) SA 654 (A)

8. McQuoid-Mason DJ. Malicious proceedings. In: Joubert WA, Faris JA, eds. Law of South Africa. Vol. 15. 2nd ed. Durban: LexisNexis, 2008:189-220.

9. Prinsloo v Newman 1975 (1) SA 481 (AD).

10. Cf. Michael v Linksfield Park Clinic (Pty) Ltd 2001 (3) SA 1188 (SCA).

11. Cf. Gayre v SA Associated Newspapers Ltd 1963 (3) SA 376 (T).

12. Regulations relating to the conduct of inquiries into alleged unprofessional conduct under the Health Professions Act, 1974. GN R102 in Government Gazette 31859 of 6 February 2009: reg 4. 